\title{
"THE EFFECT OF MULTIPLE INTELLIGENCES ON STUDENT LEARNING ACHIEVEMENT OF ELEMENTARY SCHOOL STUDENTS IN CENTRAL JAVA."
}

\author{
Abu Dharin', C. Asri Budiningsih ${ }^{2}$, Muhammad Nurwangid ${ }^{3}$ \\ ${ }^{1}$ IAIN Purwokerto, Indonesia ${ }^{2,3}$ Universitas Negeri Yogyakarta, Indonesia Corresponding Author: \\ abudharin@iainpurwokerto.ac.id
}

\begin{abstract}
:
Multiple intelligences-based learning helps students to develop the intelligence they have, Students can be helped to improve their intelligence and increase their weaknesses through the strengths they have. In addition, as a teacher as well as a teacher educator, it will be easier for them to develop the skills and talents of their students. This study aims to determine the effect of Multiple Intelligences on learning achievement in elementary schools in Central Java. The method used in this research is an experimental method such as explanatory research. The data were obtained from the Multiple Intelligences questionnaire and analyzed using multiple linear regression. From these results the study shows there is no significant difference between linguistic, logic and intelligence intra personal on the learning achievement of elementary school students. The analysis shows that the variables of linguistic, logical and intrapersonal intelligence have an influence on learning achievement
\end{abstract}

Keywords:

Multiple Intelligences, linguistics, logic, interpersonal, academic achievement, elementary school

Article Received: 18 October 2020, Revised: 3 November 2020, Accepted: 24 December 2020

\section{INTRODUCTION}

Multiple intelligences are the various skills and talents of students in solving various learning problems (Madyawati, 2016). So that students are able to solve learning problems in an amazing way (Said \&Budimanjaya, 2015).Multiple Intelligences which in Indonesian is translated as multiple intelligence or multiple intelligenceis one of the theories of intelligence that has received a lot of recognition recently. The concept of multiple intelligences learning focuses on the realm of uniqueness to find the strengths of each child. Includes learning activities for knowledge, attitudes, and skills (Chatib, Human School, 2015,). Multiple intelligence learning starts from the preparatory stage, namely the MIR (Multiple Intelligences Research) is held to find out the most prominent intelligence tendencies of students. Research on multiple intelligences-based

learning has been done before (Baş, 2016; Madkour\& Mohamed, 2016; Setiawan, 2019; Shearer \&Karanian, 2017; Si'ayah\&Setiawan, 2019; Yaghoob\&Hossein, 2016). According to
Gardner, intelligence is defined asan ability, with its completeness process, capable of dealing with the content of a specific problem in the world.However, that does not mean that people who have a certain type of intelligence, musical intelligence for example, willdemonstrate this ability in every aspect of his life. The presence of traits in an individual determines the level of his intelligence profile.In real life, these intelligences are present and appear together or sequentially in one or more activities. In special cases, suspectedthere are savant individuals, namely people who have a very high level of intelligence in one type of intelligence, but low in another. Inworld of education, the theory of multiple intelligences.began to be accepted because it was considered more serving all the intelligence a child has. Concept MI makes educators see wiser differences, and make children feel more received and served. This concept "Erase" the myth of smart children and not smart, because according to this concept, all children intrinsically intelligent. It's just a smart concept it needs to be redefined on a new basis. According to the 
General Language Dictionary Indonesia, the notion of achievement is the result that has been achieved (from what has been done, done, and so on) (1991). Meanwhile, according to SaifulBahriDjamarah (1994) in his book Learning Achievement and Teacher Competence, that achievement is what can be created, results work, a result that pleases the heart obtained by tenacity work. In the same book, NasrunHarlasi, argues that achievement is an assessment of education about student development and progress with regard to mastery of lesson material presented to students. This intelligence is one factors that influence the learning process learners. This research is more stressful on the intrapersonal development process intelegent, mathematical intelegent and linguistic intelligence. This is based because the development of learning of students on the college emphasizes the process effective and meaningful learning. With know the three intelligences, students can diagnose anythingthat need to be addressed in the learning process thus making the learning process become effective and able to cultivate thought patterns long and can solve problem logically.According to Armstrong (Alamsyah Said \&AndiBudimanjaya, 2015), the multiple intelligence learning strategy is a way of accessing information through the eight intelligence pathways that exist for each student, but to bring back all intelligence synergize in a unique unit according to needs. So that students are able to solve learning problems in an amazing way. Armstrong further stated that multiple intelligence theory allows teachers to develop innovative learning strategies that are relatively new in the world of education. However, Armstrong added that there is no series of learning that works effectively for all students. Every student has a certain tendency towards the eight existing intelligences (Alamsyah Said \&AndiBudimanjaya, 2015). Thus, the ideal learning is learning that involves students as learning subjects (student centered) with the support of the teacher as the main role in the learning process. Before starting a lesson, the teacher should prepare and pay attention to the type of intelligence that stands out the most in students in order to determine the right learning strategy in optimizing the potential that exists in students.

Multiple intelligences. Multiple Intelligences between specific theoretical intelligences includes the diversity of individual characteristics, and leads to a more effective and sensible approach to addressing each student's uniqueness in the classroom. The implications for educators and students are tremendous in terms of the richness and flexibility of the Multiple Intelligences in teaching and learning activities. As educators develop and utilize pedagogy that consciously tries to engage students in a variety of ways, knowing the intelligence students possess is essential for effective instruction. This gives this evaluation two fold benefits. If teachers know the strengths of their students, then they will be able to better prepare interesting and relevant lessons related to those strengths. Second, students know their strengths, so they can engage various strategies to improve their learning accordingly (Griggs et al, 2009). The power and potential of teaching educators who are flexible in their methods and approaches to address diverse students with different skills or potentials. This is supported by Haley (2004) who explores the application and suitability of multiple intelligences (Multiple Intelligences) in shaping and informing learning strategies, curriculum development and alternative forms of assessment for all second language learners. The two language learners are more than any other group in the class is the wide diversity that characterizes today's classrooms and schools, and the application of MI as reported by Haley (2004) proves the strength of Gardner's Theory as the most effective learning to be used in 21 st Century education and teaching. Students learn about differences and there is no doubt about it.

Some students are visual learners, while others are kinesthetic learners, and others combine several modes of learning based on their respective 
intelligence. This all requires that educators who are varied and teaching effectively reach out to students and meet the standards of accountability (Griggs et al., 2009). In their study proving the variability of student intelligence as a rationale for educators of various pedagogies based on the existence of Multiple Intelligences (Griggs et al., 2009) found that among 167 students across different disciplines, "the registered intelligences were mostly self and social, both in height of $60 \%$, followed by body movement at $47.2 \%$. Nature, music and language all followed by percent in their 20s. The two lowest listed intelligences are: logic / math and spatial, both at $17+\%$ "(p. 59). This is sufficient evidence for some of the most effective intelligences learning for clues across the cohort.

The social theory of Robert J. Stenberg (1985) sees intelligence as behavior and this behavior in individuals arises from a balance between 3 faculties or abilities: (i). Analysis, (ii) creative, and (iii) practical; which collectively constitute human intelligence. According to him Stenberg (2004): Analytical ability enables individuals to evaluate, analyze, compare and contrast information. Creative abilities generate inventions, inventions, and other creative endeavors. Practical the ability to discuss at once by allowing individuals to apply what they have learned in an appropriate setting. When examining the creative, analytical and practical ideas of intelligence, it can be seen that this displays the potential that includes the nine intelligences described by Gardner. Derived from the idea that "creativity" broadly presents itself as a potential that includes the nine intelligences described by Gardner.Stems from the idea that "creativity" is broadly defined to include one of the nine types of intelligence communicated by Gardner. Practical intelligence includes multiple intelligences, especially seen in mechanical intelligence rather than intellectual or abstract.

\section{METHOD}

The research method used is an explanatory research which seeks to explain as well as seeing the relationship between the variables contained in the study and explaining the influence of the independent variables on dependent variable, in addition to testing the proposed hypothesis, which has been previously formulated. The population in this study were all elementary school students in Central Java. The sample is part of the number and characteristics of the population. The sample taken must be representative, meaning that it must be true represent. (Sugiyono, 2010). The sample in this study was elementary school students. The sampling technique used probability Sampling is a way of taking samples which are taken randomly or randomly, namely sampling with certain considerations. It is said with certain considerations because the samples taken are elementary school students. By type and the source of the data collected, the data collection techniques used are questionnaires, interviews and observation. While the type of data is using primary data and secondary data. In this study the object of research consists of two variables, namely the independent variable and the dependent variable. The independent variable is a number of symptoms with various elements or factors in which determine / influence the existence of other variables, namely: logistical intelligence, intrapersona and interpersonal. While the dependent variable is a number of symptoms with various elements / factors in it that are determined / influenced by the presence of other variables, namely learning achievement. An operational definition is a definition given to a variable or construct by giving meaning, or specifying clarity, or provide an operation needed to measure the construct or variable (Sugiyono, 2010). Researchers who use instruments which composed alone cannot let gohimself from the responsibility of the pilot instruments, so that when used for collect data, the instrument is already really good. The purpose of this trial is obtaining quality informationthe instrument used, namely information regarding already and not 
which instrument concerned meets the requirements. The instrument can be said to fulfill requirements as a data collection tool is if at least an instrument is valid and reliable (Arikunto, 2006). Then it takes a validity test and reliability to test the instrument research. Data analysis techniques using qualitative analysis and quantitative analysis. Tool The analysis used is linear regression simple, multiple regression analysis, testing hypothesis.

\section{RESULT AND DISCUSSION}

In the validity test, each variable item validity will be tested, to find out the validity of each question item in research instruments can be seen through Corrected item-total correlation column. If Corrected item-total correlation values are more greater than $r$ table or $>0.321$ then the statement is declared valid Ujireliabilitasdilakukandenganuji Alpha Cronbach. Apabilanilai Alpha Chronbachlebihbesardari

0,5makadapatdikatakanreliabelataudapatdianalisis lebihlanjut. Berikutiniakandisajikan table hasilperhitunganreliabilitassetiap variable. Hypothesis testing in this study uses multiple linear regression, this analysis is intended to determine the influence of the independent variables (independent), namely: linguistic intelligence, logical intelligence, and intrapersonal and variable intelligence Student learning achievement as the dependent variable or the affected (dependent). The purpose of the Normality test is to find out whether in a model regression, the independent and dependent variables or both have a normal distribution or not. A good regression model is data distribution normally or close to normal.From the table above it is known that the value significance or probability of all variables 0.05 , it can be concluded that all research variables have data distribution normally distributed. Multicol test aims to test whether the regression model is found correlation between independent variables (independent). A good regression model shouldn't there is a correlation between the variables independent. If the independent variables are mutually correlated, then these variables are not orthogonal (Ghozali 2007). To detect the presence of multicollinearity, can seen from the Value Inflation Factor (VIF). When the VIF value> 10, occurs multicollinearity. Conversely, if VIF $<10$, multicollinearity does not occur (Wijaya, 2009). Analysis of the coefficient of determination (R) used to find out how big donations given by independent variables to the dependent variable shown by percentage. From the results of data analysis obtained R2 of 0.079 this shows that the variables of linguistic intelligence, logic and intrapersonal to have a contribution influence on learning achievement variables $7.9 \%$ and the remaining $92.1 \%$.Influenced by other variables that are not researched. The $t$ test is carried out to prove that a model's regression coefficient statistically significant or not, then the test is used t.

Based on the results of data analysis has been done at SPSS it is known that the linguistic intelligence variable is equal to 0.82 with a significance level of 0.05 . So it can be concluded that the tcount<ttable $(0.82<2.390)$, then for variables linguistic intelligence (X1) hypothesis $\mathrm{H} 0$ accepted means that linguistic intelligence has no effect on learning achievement (Y). Based on the results of data analysis conducted at SPSS, it is known that tcount of the logic intelligence variable is equal to -2.368 with a significance level of 0.05 . So that It can be concluded that the value of tcount $<$ ttable $(-2,386<2,390)$, then for variables Intelligence logic (X2) hypothesis $\mathrm{H} 0$ is accepted meaning that logical intelligence is not affects learning achievement (Y).Based on the results of data analysis has been done at SPSS it is known that tcount of intra personal intelligence variable is amounting to 0.549 with a significance level of 0.594 . So it can be concluded that the tcount<ttable $(0.549<2.390)$, then for variables Intelligence logic (X3) hypothesis $\mathrm{H} 0$ is accepted meaning that intra-personal intelligence is not affects learning achievement (Y). Test F is used in 
this study for know the influence between variables, namely

independent and dependent variables together. Based on the results of calculations withusing the SPSS program with a degree a significance of 0.05 obtained Fcount of 1.947. By comparing the value of Fcount with Ftable value $(1.947<2.19)$ and probability valueequal to $0.183>0.05$, the intelligence variable linguistic, logical and intra personal together or simultaneously have no effect significantly on learning achievement. Based on data processing and analysis that has been done, the results of this study concluded that there is no significant effect significant between linguistic intelligence, logic and intra personal on learning achievement elementary students. This matter shown based on the results of the $\mathrm{F}$ test with Fcount $<$ Ftable $\quad(1.947<2.19)$, and value probability of $0.138>0.05$ then linguistic, logical and intra intelligence variables personal together or simultaneously does not significantly affect student achievement of elementary school student. There is no significant effect between linguistic intelligence and achievement student learning. For the intelligence variable linguistically, the value of tcount $<$ ttable $(0.28<$

2.390), then for linguistic intelligence (X1).hypothesis $\mathrm{HO}$ is accepted with the assumption that linguistic intelligence does not provide significantly influence learning achievement (Y). Linguistic intelligenceis a demonstrated intelligence with one's sensitivity to sound, structure, meaning, function of words and language. There are several factors at play linguistic intelligence in this study including proficiency in communication, the ability to discuss, rich in vocabulary and able to read with high understanding. If a student able to apply the factors into the learning process in the classroom then linguistic intelligence can continue to evolve well and this will have an effect on student achievement. However the problems that arise here are weak level of analyst ability students in analyzing a the problem. This can be seen when it happensgroup discussion. The majority of students just askalakadarnya or ask questions as a formality. If this continues be left then linguistic intelligence students cannot thrive maximum. There is no significant effect between logic intelligence on achievement learning elemtary student the value obtained in the logical intelligence variable tcount $<$ ttable $(-2,386<2,390)$, then forintelligence variable logic (X2) hypothesis $\mathrm{HO}$ accepted means that logical intelligence is notsignificantly influence learning achievement (Y). Logical intelligence is an intelligence characterized by sensitivity to logical and possessing patterns the ability to digest these patterns, including numerical and capable of processing long line of thought. Intelligence This logic is influenced by several factors among them, estimating functions and relationships, experimenting, finding a way exit the logical and think abstractly. In this study, logical intelligence invisible to make an impact on learning achievement. This is because students' ability in composingan abstract thought and relate it to that thought logically still weak. The majority of studentsstill having trouble solving a analytical problems. This matter seen when a student is given aanalysis questions, the way they are in solve a problem sometimes out of context of the problemthat is discussed. If not resolved immediately of course will have an effect on development of intelligence and achievement learn it.

There is no significant effect between intra personal intelligence against student achievement of elementary student. On the intra personal intelligence variable obtained the value of tcount $<$ ttable $(0.594<2.309)$, then for the intra personal intelligence variable (X3) hypothesis $\mathrm{H} 0$ is accepted, meaning that intra personal intelligence has no effect significantly on learning achievement (Y). Intrapersonal intelligence is a intelligence characterized by abilitydigest and respond appropriately to the atmosphere people's hearts, temperaments, motivations and desires other. As for the factors that are affect this 
intelligence is communicate, lead andorganize groups and collaborations in the team. In this study the influence intrapersonal intelligence is not visible or does not affect learning achievement college student. This is due to a lack of attitude appreciate what is still visible among some students and this can be threatens that unity and integrity formed in one known container as a mother's extended family. Testinghypothesis indicates none the positive and significant influence of the variable linguistic, logical and intra personal intelligence on the learning achievement of majoring students. Result it shows that ability students in analyzing the incident occurs an environment is still spelled outlow. This condition can be seen when ongoing discussion, on average students are still indifferent and more rely on google both when presenting nor ask questions. other than thatstudents also just ask questions as a formality only. According to Dalyono (2009) someone whohave good intelligence generally easy learning and the results tend to be good. Conversely people who have intelligence low tend to experience internal difficulties learn, slow to think so that achievement tends to be low. These results show that the students' abilities are in analyze the events that occur a the environment is still relatively low. This condition can be seen during the discussiontook place, the average student was still indifferent and rely more on google both when presentations and ask questions. In addition, students also ask only just as a formality. The majority of students still have difficulties in developing that understanding they have so their mindset cannot form properly. as a result they will be in trouble when they get questions in the form of analysis because of logic they don't go well. Lots students who still can't read the mood of her friend sometimes can lead to conflict. Ability students in motivating themselves too still lacking so their response when accepting lectures from lecturers became indifferent indifferent. Because they still think about college just come and sit which is important leaving will definitely get that value very nice. Of course this is what should be addressed in order to create graduates who competent and high sensitivity to the surrounding social conditions. Effective communication is characterized with good social relationships (Moekijat 1984: 33). Communication failure occurs when the content of our message is understood, but the relationship among the communicants became corrupted.

Students who have a tendency to kinesthetic intelligence will find it easier to process information through movement. They are more comfortable communicating their wishes and messages with demonstrations (Jasmine, 2012). Activities carried out by the teacher in order to develop the kinesthetic intelligence of their students include playing ball catching dexterity games, performing group dancing (movements and songs). In addition, there are also activities such as monthly swimming, fun cooking and assembling activities that have been designed by the school system to be able to support and develop kinesthetic intelligence and other intelligences.

Musical intelligence is an intelligence that is identical to singing and musical instruments. This intelligence is often developed by the teacher through singing activities at the beginning of learning when doing alpha zones or when learning. In addition, the teacher also plays musical accompaniment while the lesson is in progress. It aims to encourage students to learn by providing musical accompaniment.

Interpersonal communication is declared effective when meeting communication is your thing which is fun for the communicant. If we are hang out with fun people then there will be communication fun. Every communication interpersonal, we are not just convey the message content, but also determine the level of interpersonal relationships. Slowly study interpersonal communication shift from message content to relational aspects. The better the interpersonal relationship, the better it will be things happen like, more and more open up 
someone expresses his feelings, tend to examine his feelings deep, and tend to hear with attentive and acting. It's getting better someone's relationship the more open someone to reveal himself, the more carefully perceptions of others and perceptions himself, so the more effective communication

which takes place between the communicants.Irwanto (1997: 105) argues that learning is a process of change from not being able to become capable and occurs in a certain period of time. Meanwhile, according to Mudzakir (1997: 34)learning is a business or activity aims to make changes within someone, including changes in behavior, attitude, habits, science, skills and so on. In the learn, students experience the process themselves from not knowing to knowing, because of that according to Cronbach (SumadiSuryabrata, 1998: 231) learn as well as possible is by experiencing and in experience that students use five senses. The senses are unlimited only sense of sight, but also applies to the other senses. Learning can is said to be successful if there is a change in students, but not all behavior change can be said to be learning because of changes in behavior due to learninghas the characteristics of a distinctive embodiment (Muhibbidin Shah, 2000: 116). Betweenchange is change intentional. Intentional change is change in the learning process is dueexperience or practice done on purpose and consciously. On this feature students realize that there is a change in him, like additions knowledge, habits and skills. The next change is ChangePositive and active. Positive Change means these changes are good and beneficial to life as well as in accordance with expectations because acquiring something new, more better than before. Meanwhile, active means these changes occur because of the existence the efforts of the student concerned. The last change in behavior is a result learning is effective and functional learning. Change is said to be effective when it brings certain effects and benefits for college student. While the changes are functional means changes in yourself the student is relatively sedentary and if needed these changes can reproduced and utilized again. Based on the description above, it is possible concluded that learning is a process efforts made by students to get a change in behavior whole new, on purpose, realized and the change is relative stay and bring influence andpositive benefits for students in interact with the environment.To get an achievementis not as easy as imagined, because it requires struggle and sacrifice with a variety of challenges to be faced. Assessment of learning outcomes student to find out how far he is has achieved this learning goal referred to as learning achievement. Such thatsaid by Winkel (1997: 168) thatthe learning process experienced by students produce changes in fields of knowledge and understanding, deep areas of values, attitudes and skills. Existence these changes are visible in achievement learning produced by students to a question, problem or task given by the lecturer. Through learning achievement students can find out the progress which he has achieved in learning.

Someone who has high interpersonal intelligence will have good social skills (Chatib, 2013). In addition, it was seen several times that the teacher asked students to teach their friends related learning materials that did not understand. Other activities provided by the teacher are facilitating students to carry out group discussions and group work.Intrapersonal intelligence characterizes a person's ability to think reflectively, which refers to awareness of one's own feelings and thought processes. According to Muhammad Yaumi, developing intrapersonal intelligence can be done by giving independent tasks, reflecting, helping to create self-identity, and expressing feelings (Yaumi, 2013). There are many psychological factors that can beaffect student achievement,among others, is intelligence. In general,learning achievement displayed by studentshas a close relationship with the levelintelligence possessed by students. According toBinet (Winkle, 1997: 529) the nature of intelligenceis the ability to assign andmaintain a 
goal, formake an adjustment in orderachieve that goal and to assess the situationyourself critically and objectively. Intelligence levelthis greatly affects learning achievementa student, where a student

have a high level of intelligence havegreater opportunities for achievementhigher learning. Otherwise,students who have a level of intelligencelow is expected to also havelow learning achievement. But it is notsomething that would be impossible if a studentwith a low level of intelligence havehigh learning achievement, and vice versa.The next psychological factor tooinfluencing student learning achievement isattitude. Passive, low self-esteem and lack of attitude

self-confidence can be a factorhinder students in displayingstudy achievement. According to SarlitoWirawan(1997: 233) attitude is a person's readinessto act in a certain way on thingscertain. Positive student attitudetowards courses on campus isa good first step in the learning processteaching on campus. Motivation is also aaspects that affect achievementstudent learning. According to Irwanto (1997:193) motivation is a behavior driver.Motivation to learn is someone's driving forceto learn. Motivation arises because of itwants or needs inoneself. Someone succeeded instudy because he wants to learn. Whileaccording to Winkle (1997: 39) learning motivationis the entire driving force withinstudents who give rise to activitieslearning, which ensures continuity fromlearning activities and that provide directionon that learning activity, then that goalachieved by students.Motivation to learn is a psychological factornon intellectual. Its distinctive roleis in terms of passion or enthusiasm for learning,students who are strongly motivated willhave a lot of energy to dolearning activities.External factors are other mattersoutside yourself which can affect performancelearning that will be achieved by the participantsstudents / students. Several factorsexternal factors are environmental factorsfamily. In the family environmental factorthere are at least four things that giveinfluence on student achievement, the first is socio-economic conditionsfamily. With its socioeconomicadequate, someone more opportunitiesget better learning facilities,from books, stationery to selectionschoolSecond, parental education. Parentswho have taken educationtall tend to pay more attention andunderstand the importance of education for their children,compared to thathave a higher education levellow. Third, the attention of parents andatmosphere of relationship between family members.Support from family is abooster aspiration for someone.Support in this case can be direct,in the form of praise or advice; or byindirect, like a family relationshipharmonious. The next external factors tooalso affects learning achievementstudents are environmental factorslectures. In environmental factorslectures there are several things that needget attention if learning achievementstudents / learners want to be improved.First, facilities and infrastructure. Completenesscampus facilities, such as blackboards, OHP willhelp the learning process smoothteaching on campus, apart from the form of the room,air circulation and the environment around the schoolcan also affect the learning processteachSecond, the competence of lecturers andcollege student. Quality of lecturers and studentsvery important in achieving achievement,completeness of facilities and infrastructure withoutaccompanied by good performance from theits users will be useless. If athe student feels the need todo well on campus is fulfilled,for example, with the availability of facilities andqualified educators, who canfulfill his curiosity, relationshipwith lecturers and friendstake place harmoniously, then the student willacquiring a climate of learningfun. Thus, he willdriven to continually improvestudy achievement.Third, the curriculum and methodsteach. This includes material andhow to provide that materialto students. Learning methods aremore interactive is very necessary forfoster interest and participationstudents in 
learning activities.SarlitoWirawan (1997: 122) said

that the most important factor isthe teaching force factor. If the teaching staffteach wisely, firmly,have high discipline, flexible and capablemake students happylessons, then student learning achievementwill tend to be tall, at least studentsit doesn't get bored in followinglectures.Fourth, the next external factorwhich also affects learning achievementstudents are a community environment.In the community there is astigma regarding the importance of education willaffect the seriousness of educators andlearners. The still societylooking down on education will be reluctantsend his son to campus andtend to look down on workteaching / teaching staff. Participation againsteducation is also an integral partfrom the community. When all partieshas participated in and supported the activitieseducation, starting from the government (in the form ofpolicy and budget) up tosociety down, everyone will be morerespect and seek to improveeducation and science. In the middleincreasingly intense competition in the worldeducation today, is a thingit is natural that students are often worriedwill experience failure or notsuccess in achieving learning achievement.It is difficult for students to learn without encouragement. When students study unlike what they learned, they feel bored and tired even if they are not able to study well and do well on the final exams. Therefore, it is better to create a pleasant classroom atmosphere where students like what they are learning and enjoy. Using the theory of Multiple Intelligences in the classroom can help educators to create an atmosphere of joy.Gardner's theory supports an understanding of diversity and multiculturalism. Howard Gardner coined the term Multiple Intelligences as a result of his research studying human potential. $\mathrm{He}$ also defines intelligence as the ability to solve problems or understand problems in one or more cultural settings and situations (Gardner, 1993; Strassers, J \&Seplocha, H, 2005).

\section{CONCLUSION}

Based on the results of the research and discussion that has been described, it can be concluded that the learning preparation that has been carried out by the school and the teacher is to recognize the intelligence of students through Multiple Intelligences Research (MIR) and Student Maturity Orientation as well as compiling lesson plans / lesson plans accordingly. with the national curriculum curriculum, but it does not include the type of intelligence that will be developed in learning.This research can be used as an alternative learning system that helps students develop their intelligence and talents. Multiple Intelligences can also be recommended for parents to better understand their children's abilities. So that parents can direct their children without imposing their will. Guide attentively without using physical or verbal violence.Many efforts were made by the students to achieve learning achievements in order being the best like following tutoring, additional classes or ask directly to the lecturer concerned about the course materialconsidered clueless. That kind of venture clearly positive, but there are other factors that are no less important in achieving success other than intelligence or intellectual prowess, these factors are linguistic intelligence, logic, and intra personal. Because intellectual intelligence alone is not provide preparation for individuals to face turmoil, opportunity or hardships and life. With linguistic intelligence, individual able to use words effectively both orally and in writing. This matter is an important part of prospective teacher students. Because the teacher is place as a knowledge transfer process acquired and then given understanding to students. The point is if the teacher lacks the ability use words properly then you can it is thought the process of transforming science too slow or fail. Logic intelligence or in the term is math intelligence is the ability to process numbers and use logic or common sense with good. Problems obtained from research this 
is the majority of students still difficulty developing understanding that they have so their mindset cannot form properly. as a result they will be in trouble when they get questions in the form of analysis because of logic they don't go well. even though as a prospective teacher of this intelligence necessary in order to produce a explanations that aren't just book based text, but analysis is also needed through other relevant sources with the teaching material delivered. Intra personal intelligence is a individual ability to perceive and distinguish moods, intentions, motivations as well as people's feelings. Through this intelligence individuals in general and prospective teachers on in particular will have the ability respond to their own feelings with good and able to read and face other people's feelings. It is over closely related to emotional skills. This means most likely individual will succeed in life and have the motivation to excel. Whereas individuals who cannot hold back control over his emotional life will experience destructive inner battles his ability to focus on his duties and have thoughts clear. A report from the National Center for Clinical Infant Programs (1992) states that one's educational success not predicted by a collection of facts a student or his abilities to read, but rather by measure emotional and social namely in self own and have interests, know patterns behavior that others expect and how to control impulses to misbehave, to be able to wait, follow directions and refer to the teacher to seek help, as well as reveal needs when associating with other students. Almost all students are good achievement the school is bad, according to the report, lacks one or more elements this emotional intelligence (without care if they too have cognitive difficulties likelearning disabilities). (Goleman, 2002: 273). This is what at least to be concern for us teacher teacher lecturers / prospective teachers, to always pay attention the development of multiple intelligences from each of our students in order multiple intelligences can and can useful for improving quality science as a researcher and professionalism as a teacher later day.

\section{REFERENCE}

[1] Akbari, R., \& Hosseini, K. (2008). Multiple intelligences and language learning strategies: Investigating possible relations. System, 36(2), 141-155

[2] Campbell, L., Campbell, B., \& Dickinson, D. (1996). Teaching \& Learning through Multiple Intelligences. Allyn and Bacon, Simon and Schuster Education Group, 160 Gould Street, Needham Heights, MA 021942315 (Order No. H63373, \$27.95, plus shipping and handling)..

[3] Efobi, A. \& Nwokolo, C. (2014). Relationship between Parenting Styles and Tendency to Bullying Behaviour among Adolescents. Journal of Education and Human Development, 3 (1).

[4] Armstrong, T. (1994). Multiple intelligences: Seven ways to approach curriculum. Educational leadership, 52(3), 26-28.

[5] Ferguson, C. (2010). Genetic Contributions to Antisocial Personality and Behavior: A Meta-Analytic Review from an Evolutionary Perspective. The Journal of Social Psychology, 150 (2).

[6] Gardner, H. (2003). Multiple intelligences after twenty years. American Educational Research Association, Chicago, Illinois, 21, 1-15.

[7] Ghozali, I. (2014). Structural Equation Modeling, Metode Alternatif dengan Partial Least Square (PLS). Edisi 4. Semarang: Badan Penerbit Universitas Diponegoro.

[8] Herman, A.E. and Scherer, L.L. (2008), "Chapter 3 The effect of emotional intelligence and cognitive intelligence on the solutions generated to ill-structured problems", Zerbe, W.J., Härtel, C.E.J. and Ashkanasy, N.M. (Ed.) Emotions, Ethics and Decision-Making (Research on Emotion in 
Organizations, Vol. 4), Emerald Group Publishing Limited, Bingley, pp. 57-81.

[9] Huver, R. M . E. et al. (2010). Personality and Parenting Style in Parents of Adolescents. Journal of Adolescence, 33.

[10] Hasnain, B.F. \& Adlakha, A. (2013). Self Esteem and Happiness of Children and Mothers of Different Parental Authority. The International Journal of Humanities and Social Studies, 1.

[11] Jonyniene, J. \& Kern, R.M. (2012). Individual Psychology Lifestyles and Parenting Style in Lithuanian Parents of 6 to 12 Years Old. International Journal of Psychology.

[12] Morgan, G. (2019), "A Case for Narrative Intelligence", Rewriting Leadership with Narrative Intelligence: How Leaders Can Thrive in Complex, Confusing and Contradictory Times, Emerald Publishing Limited, pp. 7-105. https://doi.org/10.1108/978-1-78756-775720191008

[13] Miles, D. \& Carey, G. (1997). Genetic and Environmental Architecture of Human Aggression. Journal of Personality and Social Psychology, 27(1).

[14] Misbach, I. H. (2010). Dahsyatnya Sidik Jari Menguak Bakat dan Potensi untuk Merancang Masa Depan Melalui Fingerprint Analysis. Jakarta: Visi Media.

[15] Academic Achievement. American Journal of Social and Management Science.

[16] Oktafiany, N. D. dkk. (2013). Correlation of Parenting Method to the Sudents Emotional Quotients of Diponegoro 1 Jakarta Junior High School. Jurnal UNJ Online, 1(2).

[17] Othman, N. \& Khairollah, S. (2013). Exploring the Relationship between Islamic Personality and Parenting Style. International Journal of Islamic Thought, 4.

[18] Roscoe, J. (2001), "Profiting from Multiple Intelligences in the Workplace", Industrial and Commercial Training, Vol. 33 No. 4. https://doi.org/10.1108/ict.2001.03733dae.0 02

[19] Robinson, C. et.al. (1995). Authoritative, Authoritarian and Permissive Parenting Practices: Development of a New Measure. Psychological Reports, 77, 819-830.

[20] Roman, N. et.al. (2015). Parenting Styles and Psychological Needs Influences on Adolescent Life Goals and Aspirations in A south African Setting. Journal of Psychology in Africa, 25(4).

[21] Santrock, J. W. (2008). Psikologi Pendidikan. Jakarta: Kencana Prenada.

[22] Samani, M. \& Hariyanto. (2011). Konsep dan Model Pendidikan Karakter. Bandung: Remaja Rosdakarya.

[23] Shmueli Gabel, R., Dolan, S.L. and Luc Cerdin, J. (2005), "Emotional intelligence as predictor of cultural adjustment for success in global assignments", Career Development International, Vol. 10 No. 5, pp. 375-395. https://doi.org/10.1108/13620430510615300

[24] Setiawan, D. (2018, Maret 6). KPAI CatatAnakDimanfaatkanJadiKurirNarkoba. <https://www.kpai.go.id/berita/kpai-catatanak-dimanfaatkan-jadi-kurirnarkoba> Diakses: 15 Oktober 2019.

[25] Sugiyono. (2014). Metode Penelitian Kuantitatif dan Kualitatif. Bandung: Alfabeta.

[26] Talib, Johari et.al. (2011). Effects of Parenting Style on Children Development. World Journal of Social Sciences, 1(2).

[27] Utomo, D. (2014). Intensi Perilaku Prososial Anak Ditinjau dari Gaya Pengasuhan. Jurnal Online Psikologi, 2(1). 